\title{
Erratum to: Antimony Assessment in PET Bottles for Soft Drink
}

\author{
Paulo Henrique M. Kiyataka ${ }^{1}$ - Sílvia T. Dantas ${ }^{1}$ Aline Cristina Albino ${ }^{1}$. \\ Juliana Azevedo Lima Pallone ${ }^{2}$
}

Published online: 31 August 2017

(C) Springer Science+Business Media, LLC 2017

\section{Erratum to: Food Anal. Methods}

DOI 10.1007/s12161-017-0951-x

The original version of this article unfortunately contained mistakes. Section "Introduction", fourth paragraph should read: In Brazil, RDC Resolution 17/2008 (BRASIL 2008), published by ANVISA, the National Health Surveillance Agency, establishes a positive list of additives for plastic materials intended for the production of packaging and equipment that comes into contact with food and has authorized the use of antimony trioxide in the manufacture of PET resin. It has fixed a specific migration limit for antimony in packaging of $40 \mu \mathrm{g} \mathrm{kg}^{-1}$, which is the same limit established by the EU regulation EC 10/2011 (EU 2011), while in Japan, the Japan External Trade Organization has established a limit of $50 \mu \mathrm{g} \mathrm{L}{ }^{-1}$ (JETRO 2011). The Food and Drug Administration (FDA) has not specified a migration limit for antimony from PET packaging materials (Welle and Franz 2011).

The original article was corrected.

The online version of the original article can be found at http://dx.doi.org/ 10.1007/s12161-017-0951-x

Paulo Henrique M. Kiyataka

paulok@ital.sp.gov.br

1 Centro de Tecnologia de Embalagem, Instituto de Tecnologia de, Alimentos - ITAL, Campinas, SP 13070-178, Brazil

2 Departamento de Ciência de Alimentos, Faculdade de Engenharia de Alimentos, Universidade Estadual de Campinas-UNICAMP,

Campinas, SP 13083-862, Brazil 